\title{
ЭЛЕКТРОННЫЕ ДЕНЬГИ И ОБОРОТ НАРКОТИЧЕСКИХ ВЕЩЕСТВ В РОССИИ: АНАЛИЗ И СЛОЖНОСТИ РЕГУЛИРОВАНИЯ
}

\author{
(c) 2021 Литягина Алла Сергеевна \\ старший преподаватель, Кафедра трудового и предпринимательского права \\ Института права, экономики и финансов \\ Кабардино-Балкарский государственный университет им. Х. М.Бербекова, \\ Кабардино-Балкарская Респ., Нальчик \\ E-mail: alla7878@bk.ru
}

\section{(C) 2021 Шаваева Диана Вячеславовна \\ студентка группы ЮБС19-1м,}

Департамент правового регулирования экономической деятельности Юридического факультета Финансовый университет при Правительстве Российской Федерации, Россия, Москва

В статье рассматриваются основные проблемы правового регулирования электронных денежных средств в их связи с усложнением ситуации с наркотрафиком в РФ. Предложены основные мировые подходы к определению электронных денег. Проанализировано современное состояние рынка наркотических веществ, рассмотрены новые способы торговли наркотиками: торговля через маркетплейсы в даркнете. Также в данной статье проведен точечный анализ лидера на рынке цифровой наркоторговли, приведена статистика правоохранительных органов и здравоохранительных организаций, а также исследования независимых СМИ в этой части. Затронуты ключевые особенности российского теневого рынка наркоторговли и выявлены основные сложности борьбы и превенции подобных преступлений.

Ключевые слова: электронные деньги, наркотики, теневой рынок, цифровая наркоторговля, криптомаркет, отмывание доходов

Процент использования электронных денег при совершении платежей растет с каждым годом в мировых масштабах. Популярность данного способа осуществления денежных операций повышает не только его простота и удобство, но и повсеместное развитие цифровых технологий в сфере финансов. Финансовый рынок уже достаточно давно перешел в режим «онлайн», время биржевых ям и офисного банкинга постепенно уходит в прошлое - человечество «оцифровывает» теперь не только учетные данные, но и валюту. Современный мир диктует свои условия не только крупным игрокам на рынке, но и обычным потребителям финансовых услуг. И, если новые технологии появляются ежесекундно, то законодательство, в том числе международное, не столь динамично.

Из этой проблемы вытекает и другая, более насущная - новые виды электронных денег порождают и новые способы их преступного использования. Особенно ярким примером является бурный рост российской цифровой наркоторговли. Именно это и стало центральной темой данной статьи.
Прежде, чем перейти непосредственно к схемам преступного использования электронных денег, необходимо внести ясность в понятийнокатегориальный аппарат. Так, Банк Международных Расчетов в своем глоссарии терминов, используемых при платежах и в расчетных системах, определяет электронные деньги как сумму, хранящуюся в электронном виде на таких устройствах, как карты с микрочипами, либо жесткие диски персональных компьютеров. Важно отметить, что здесь же БМР проводит различие между «электронными деньгами» и «электронными средствами платежа», вводя понятие «электронного кошелька» и «электронной банковской карты». Далее последнее понятие расширяется посредством классификации существующих видов банковских карт. Позднее, в июне 2010-го года докладом этой же международной организации понятие электронных денег было расширено. Электронными деньгами теперь считалась денежная величина, представленная правом требования к эмитенту, сохраняемая в электронном устройстве (карта с микрочипом, жесткий диск персонального 
компьютера, серверы или иные устройства), и выдаваемая после получения денежных средств в сумме, не меньше полученной денежной величины, и принимаемая в качестве платежного средства предприятиями, иными, чем эмитент.

Еще один подход к понятию электронных денег можно выделить из Директивы 2009/110/ EC Европейского парламента и Совета ЕС. Согласно ей, электронные деньги - это денежная стоимость, сохраненная электронным способом, в том числе магнитно, представленную требованием к эмитенту, которое выдается при получении средств для совершения платежных операций и принимается физическим или юридическим лицом, отличным от эмитента электронных денег. Электронные деньги могут выпускаться кредитными учреждениями, а также другими финансовыми и нефинансовыми организациями ЕС.

И, наконец, необходимо отметить российский подход к определению электронных денег, данный в ФЗ «О национальной платежной системе». Электронные денежные средства - это денежные средства, которые предварительно предоставлены одним лицом (лицом, предоставившим денежные средства) другому лицу, учитывающему информацию о размере предоставленных денежных средств без открытия банковского счёта (обязанному лицу), для исполнения денежных обязательств лица, предоставившего денежные средства, перед третьими лицами и в отношении которых лицо, предоставившее денежные средства, имеет право передавать распоряжения исключительно с использованием электронных средств платежа. При этом не являются электронными денежными средствами денежные средства, полученные организациями, осуществляющими профессиональную деятельность на рынке ценных бумаг, клиринговую деятельность и (или) деятельность по управлению инвестиционными фондами, паевыми инвестиционными фондами и негосударственными пенсионными фондами и осуществляющими учёт информации о размере предоставленных денежных средств без открытия банковского счёта в соответствии с законодательством, регулирующим деятельность указанных организаций.

Также, российским законодательством регламентировано разделение электронных денег на несколько категорий в зависимости от субъектного состава: персонифицированные электронные средства, неперсонифицированные электронные средства и корпоративные электронные средства. Отличием между персонифицированными электронными средствами и неперсонифицированными служит обязательность идентификация владельца-клиента при осуществлении операций по переводу. Подобного выбора, однако, не предусмотрено для юридических лиц-владельцев корпоративных электронных средств - все операции с участием юридических лиц осуществляются с обязательной идентификацией.

Законодателем принимаются многочисленные попытки по созданию максимально урегулированной и безопасной среды для использования электронных денег. Примечательными являются многочисленные исследования на эту от Ассоциации компаний интернет-торговли: совершение россиянами покупок онлайн дало мощный толчок рынку онлайн-торговли - с 2017 года по 2018 российский рынок вырос на 59\%. По данным организации, в 2018 году в России было произведено сделок купли-продажи через интернет на 1,66 триллиона рублей. Согласно аналогичному исследованию, в России около 46\% пользователей совершают транзакции с использованием электронных платежных средств.

Развитие и распространение электронных денег в России стало благоприятным фактором не только для отечественной экономики, но и для наркоторговли. Еще в 2013 году, Госнаркоконтроль выступил за ужесточение регулирования электронных денег, мотивируя это печально возросшей статистикой по обороту крупных партий наркотиков. Так, в 2011 г. совместными действиями ФСБ и ФСКН в Москве была задержана преступная группы из 10 жителей Ставропольского края, организовавших торговлю курительными смесями через интернет. Товар продавался на условиях 100\% предоплаты, которая осуществлялась через Webmoney, «Яндекс. Деньги», «Qiwi-кошелек». После оплаты заказы отправлялись курьерскими службами, либо «Почтой России». На квартире у злоумышленников было изъято 1,5 кг концентрата JWH, из которого можно изготовить 50 кг курительных смесей стоимостью 20 млн. руб. Данный случай является одним из самых резонансных, однако далеко не единственным.

Современный отечественный рынок наркотических веществ осуществляет свою деятель- 
ностьчерездаркнет - «теневую» часть интернета, где распространяются сведения и осуществляются сделки, имеющие преступный характер: это покупка и продажа оружия, наркотиков, порнографии, финансирование экстремистских группировок и т.д. Торговля конкретно наркотиками ведется через криптомаркеты - виртуальные анонимные площадки. В целом, подобные сайты не «живут» долго - около 8 месяцев, но это не касается крупных игроков теневого рынка. В России таких площадок действовало до недавнего времени сразу несколько, однако агрессивная конкуренция, а также громкие аресты одних из самых крупных таможенных брокеров, контролирующих грузоперевозки из-за рубежа, в частности через морские порты, привели к монополии одного определенного маркетплейса. Посредством подсчета количества отзывов на предлагаемые этой площадкой товары, было зафиксировано около 3 миллионов отдельных аккаунтов-пользователей. По окончательным расчетам, с 2016 по 2019 год пользователи внесли на 64,7 млрд. рублей (\$1 млрд. на июнь 2019). Доход маркетплейса складывался из комиссии с каждой транзакции, аукционов и «виртуальной» аренды за онлайн-магазины от отдельных поставщиков. Источник данной статистики делает важное замечание: так как, ввиду анонимности даркнета, сложности в отслеживании конкретных сумм, вышеупомянутый доход площадки мог быть еще больше.

Ознакомившись со статистикой, можно сделать следующие выводы о том, как именно электронные деньги осложняют борьбу с наркоторговлей в России:

1) Ключевой момент - платежи с целью покупки наркотических веществ осуществляются с помощью неперсонифицированных электронных денежных средств, являющихся фактически обезличенными. Около трети покупателей расплачиваются при помощи Qiwi-кошельков, остальные используют биткоины. Существует способ отследить владельца Qiwi-кошелька через привязанный номер телефона, однако мошенники зачастую используют подставные номера и б/у сим-карты. Отследить же биткоин невозможно;

2) Идентификация пользователя наркомаркетплейса - крайне трудная задача для правоохранителей. Даркнет имеет свои ключи шифрования данных, и аккаунты покупателей не оставляют цифрового следа, они так же не привязаны к каким-либо идентификационным данным клиента - один человек может легко иметь несколько аккаунтов, либо действовать через доверенных лиц;

3) Сложность превенции преступления. Так как все «сделки» по продаже наркотиков перешли в онлайн-режим, невозможно арестовать диллера-распространителя на месте преступления, ведь покупка-продажа происходит в интернете, без личного контакта, практически мгновенно. Остается лишь возможность задерживать покупателей при «снятии клада» - то есть, во время поиска обозначенного диллером места, в котором оставлена предполагаемая покупка;

4) Привлечь к ответственности по существующим в УК статьям организаторов маркетплейса будет сложно - ведь они не участвуют в транзакциях самостоятельно, а лишь создают среду для удобного поиска поставщиками клиентов и наоборот. Опять же, встает вопрос об идентификации «крупных игроков» и руководителей теневого рынка;

5) Затруднение деятельности правоохранительных органов. Сбыт наркотиков с использованием электронных платежных систем позволяет преступникам затруднить реализацию некоторых оперативно-розыскных мероприятий сотрудниками правоохранительных органов (например, проверочная закупка). Также становится бесполезной распространенная практика внедрения в преступную среду поставщиков и диллеров наркотических средств оперативного сотрудника под прикрытием;

6) Недостоверная статистика. МВД ведет свою собственную статистику по количеству преступлений, связанных с оборотом, хранением и продажей наркотиков, Минздрав анализирует количество наркозависимых граждан и смертность, вызванную этой причиной - однако, официальная статистика рассчитана лишь на зарегистрированные случаи, на тех граждан, которые попали в наркодиспансер, либо были задержаны сотрудниками правоохранительных органов. Данная статистика не распространяется на людей, употребляющих и покупающих наркотики нерегулярно, чье количество растет и не отображается в официальных отчетах;

7) Распространение пропаганды и рекламы наркотиков. В даркнете не существует функции «пожаловаться на неприемлемый контент», таким образом, навязчивая реклама, в том числе, наркотиков, легко находит своего зрителя. Огра- 
ничить действия распространителей такой рекламы не представляется возможным.

Отдельно хотелось выделить тот факт, что деятельность по отмыванию доходов, полученных путем подобной незаконной деятельности существенно упрощается. Электронные деньги легко обращаются в наличные, не неся при этом за собой никаких рисков, в отличие от бумажных денег.

Подводя итоги, целесообразно будет рассмотреть также исследование российского новостного источника, содержащее новейшую статистику в части наркотрафика в РФ. Так, в нашей стране наблюдается бурный всплеск популярности синтетических «местных» наркотиков, синтез которых происходит в мелких и средних лабораториях практически повсеместно. Этот скачок в спросе источник объясняет закрытием прежних каналов поставок наркотического сырья - ранее это происходило, в основном, через порты Прибалтики. Однако, уменьшение импортного «товара» на теневом рынке отнюдь не говорит о б улучшении ситуации в целом. В 2018 году было осуждено 685,3 тысячи человек по 228 статье УК РФ, однако лишь 19 тысяч из них было осуждено за сбыт наркотиков. Большинство осужденных получили сроки за покупку, либо за распространение. Впрочем, согласно сведениям государственных СМИ, статистика по количе- ству преступлений, совершенных по вышеупомянутой статье, снизилась в последние два года чуть ли не на четверть. Напрашивается закономерный вопрос: россияне действительно стали употреблять меньше или же раскрываемость преступлений в этой части ухудшилась?

Исходя из вышесказанного, можно сделать вывод, что регулирование электронных платежей в части лимитов на отдельные транзакции, а также неполная статистика и достаточно старомодный подход к анализу обращаемости сумм на теневых рынках являются недостаточными для эффективной борьбы с наркоторговлей на территории России. Однако не имеет смысла «запрещать» электронные деньги в целом, необходимо в первую очередь усовершенствовать регулирование неперсонифицированных денежных средств. Также, следует понимать, что возможно оплатить покупку наркотиков онлайн, но невозможно поставить их через интернет покупателю и тем более ввезти в страну, не находясь с наркотическим продуктом в личном контакте. Этот факт подтверждает необходимость более пристального анализа диллерских схем: способов поставки наркотического сырья в РФ. Именно оттачивание методики в этой сфере является гораздо более важной, чем ужесточение законодательства в части электронных денежных средств.

\section{Библиографический список}

1. «Глоссарий терминов, используемых в платежных и расчетных системах» (утв. Комитетом по платежным и расчетным системам Банка международных расчетов, Базель, Швейцария, март 2003 г.)// СПС Легалакт [Электронный ресурс];

2. «TNS: электронные деньги для оплаты за последние полгода использовали 46\% россиян», 2019 год// СМИ Банки.py, URL - www.banki.ru;

3. «Глава ULS Global Игорь Хавронов получил более 7 лет тюрьмы за контрабанду», 15 июня 2018 года// СМИ Росбалт [Электронный ресурс];

4. «Госнаркоконтроль: электронные деньги используются для наркоторговли», 2011 год// СМИ Банки.ру. URL - www.banki.ru;

5. «Исследование рынка электронных денег АКИТ»,2018 год// СМИ Лента.py, URL - www.lenta.ru;

6. «Россия под наркотиками», независимое расследование СМИ Лента.ру, 2020 год// CMИ Лента.py, URL www.darknark.lenta.ru;

7. «Цикл «Подпольная Россия»: Вся эта дурь. Исследование о том, на чем сидит Россия», Андрей Дорожный, Артур Хачатурянц, 25 июля 2019// СМИ Проект.медиа, URL - www.proect.media.com;

8. Отчет за 2018 год, Судебный департамент ВС РФ// газета Коммерсантъ, май 2018 года, № 5(12);

9. Роль и место электронных платежных систем в незаконном обороте наркотиков на территории Российской федерации, О.Н. Корчагин, Вестник Сибирского юридического института ФСКН России, № 2 (11), 2012 г.;

10. Федеральный закон Российской Федерации № 161-Ф3 г. «О национальной платёжной системе» от 27 июня 2011 года// СПС КонсультантПлюс [Электронный ресурс];

11. Электронные деньги в России: современное состояние и проблемы развития, Т. Г. Бондаренко, Е.А.Исаева, Статистика и экономика, Т. 13. № 5. 2016 год; 
12. DIRECTIVE 2009/110/EC OF THE EUROPEAN PARLIAMENT AND OF THE COUNCIL of 16 September 2009 on the taking up, pursuit and prudential supervision of the business of electronic money institutions amending Directives 2005/60/EC and 2006/48/EC and repealing Directive 2000/46/EC (Text with EEA relevance)// Eur-lex of European Union [Электронный ресурс]. 